\section{Promoting Sago Palm in The Context of National Level: Challenges and Strategies to Adapt to Climate Change in Indonesia}

\section{Marlisa Ayu Trisia*, Andi Patiware Metaragakusuma, Katsuya Osozawa and Hu Bai}

${ }^{a}$ The United Graduate School of Agriculture Sciences, Ehime University, 3-5-7 Tarumi, Matsuyama, Ehime 79o-8566, Japan

Received: November 30, 2015/ Accepted: June 19, 2016

\begin{abstract}
Indonesia is exceptionally vulnerable to the negative impacts of climate change. Anticipating this, the Indonesian government has taken several actions such as developing a National Action Plan (RAN-GRK) in 2011 to reduce emissions as well as publishing a National Action Plan for Climate Change Adaptation (RAN-API) in 2014. Despite these actions, the long-term implications of those polices for food security are not yet clear. On the other hand, Indonesia has great potential food namely sago palm. Sago palm could be an alternative crop because its production is not significantly influenced by climate. A SWOT analysis is used to examine the sago palm situation which we intend to recommend to the Indonesian government to promote sago as an alternative to adapt to climate change. The results show that the sago palm national program makes up only $0.05 \%$ of the total state budget (ABPN) during 2012-2014, a relatively small amount compared with other annual crops as well as a shifting of sago socio-culture due to the local food politics. Indeed, although sago palm has been recognized since the 1970s, its development has stalled and a comprehensive strategy involving sago palm in the long-term in relation to climate change adaptation is still lacking.
\end{abstract}

Keywords: Adaptation; Climate Change; National Level; Sago Palm; Policy.

Tel.: +8190-2894-6373 ; E-mail: marlisaatrisia@yahoo.com
Corresponding Author
Abbreviations:

RAN-GRK : National Action Plan for Reducing

Greenhouse Gas Emissions

RAN-API : National Action Plan for Climate Change Adaptation

APBN : State Budget

SWOT : Strengths, Weakness, Opportunities and Threats

\section{Introduction}

Climate change has emerged as one of the most important current global issues. The rising of greenhouse gas emissions [1] threatens every country by influencing aspects of livelihood, health, ecosystem, food security and water [2], [3]. Indonesia is the third largest emitter of greenhouse gasses in the world with a total of 3,014 $\mathrm{MtCO}_{2} \mathrm{e}$ after the United States and China [4], [5], [6]. Therefore, the Indonesian government has committed to mitigate and adapt to climate change through developing a National Action Plan to Reduce Greenhouse Gas Emissions (RAN-GRK) in 2011 which will bring down national emission levels by $26 \%$ by 2020 as business as usual and $41 \%$ with International assistance [7], [8]. In 2014, the government published a National Action Plan for Climate Change Adaptation (RAN-API) in 2014 that focuses on economic resilience (including food and energy security), living system resilience (consisting of public health, housing and settlement, and infrastructure), ecosystem resilience, specific region resilience (coastal and small islands, and urban systems) and supporting system resilience [9]. Climate change is also affecting the agriculture sector and leading to endangering food production. An increase of the local temperature by $2^{\circ} \mathrm{C}$ is projected to negatively impact yields of major crops such as wheat, rice, and maize [10]. In Indonesia, rice is the main staple food, however, recent studies have shown that a month's delay in the onset of the wet season due to climate change can decrease rice production by as much as $65 \%$ in both West and Central Java [11]. In Bali, rice paddy production has been decreased by $20 \%$ in the last 20 years due to climate change [12]. In addition to droughts attributed to the El Nino effect which has contributed to a reduction in the areas of paddy and maize cultivation [13], thereby decreasing food production. A majority of crops experienced peak production in 2006 and have been in a downward trend every year since [14]. Therefore, alternative crops more tolerate of variable climate change are necessary to ensure viable food and human security.

Sago palm is a potentially beneficial alternative crop because its production is not significantly influenced by 
climate [15]. It can play an important role in promoting food security because it contains carbohydrates in a higher proportion than rice; 84.7 per $100 \mathrm{mg}$ for sago palm compared to 80.0 per $100 \mathrm{mg}$ for rice [16]. It also produces four times more starch as rice (100-20o kilograms per palm), which is enough to feed a family for one month [17]. Sago palm is already a staple food in some area such as in West Sumatera and the Eastern part of Indonesia [18]. Therefore, sago palm could contribute to Indonesia's food security, particularly when agriculture comes under increasing pressure from changing climate patterns. Sago palm is also excellent for greenbelt vegetation because it acts as an effective sink for carbon sequestration which mitigates climate change [19]. In addition to being tolerant of tropical acidic soil, preventing soil erosion via a root system which can trap silt, it also has the ability to endure intense isolation, typhoon winds, drought, and prolonged flooding [20]. A case study conducted in the Philippines showed that sago palm experienced limited damage, only $12 \%$ from the Haiyan typhoon in 2013 [21]. Compared with paddy fields, sago palm is environmentally friendly because it conserves soil and water, acts as a buffer zone for flood and sea water intrusion, and has the capability of self-regeneration [22]. Due to these advantages, sago palm has been planted in buffer zones as a greenbelt method of rehabilitating degraded lands [23]. In intertidal areas, it could also be planted in proximity to mangrove and nipa palm to protect against coastal erosion. A research project on sago palm in the Philippines, which established a 10-kilometres buffer zone or Eco-belt by the Agusan River showed that capacity building and sago eco-belt construction could support the livelihood of local people and increase the adaptive capacity of the local community [24]. Sarawak, Malaysia, in recognition of the environmental benefits of sago palm such as flood resistance, carbon sequestration, as well as being a crop that requires zero fertilizer, are promoting it as the region's next golden crop [25].

This research presents an overview of the current state of the sago palm in Indonesian as well as demonstrating its value in the broader context of climate change. Even though many researchers worked on the physiology and utilization of sago, very few researchers studied about the possibility of sago palm to foster climate change adaptation. Furthermore, there is no comprehensive study to include or promote sago palm in proper national long-term action plans, which is studied exclusively in this paper. Diet-based research of sago is also relatively limited compared with rice, maize and cassava, yet it has a great opportunity to be developed. These assumptions emphasize our claims that this research makes an important contribution to wider literature and raise government and community level awareness of the value of sago palm. In the first section, we have defined the problems, outlined the guiding principles and summarized our findings. The second section details the data collection and the analytical methodology. The third section examines the results and discusses our analysis and finally in the fourth section, we conclude our research with reflection and a call for future research. This research does not evaluate sago palm development at the local level but advocates future comparative research examining the utility of sago palm and promotion at a central and local level in anticipation of an increasingly challenging environment.

\section{Methodology}

This research was conducted during June 2015 in Jakarta, Indonesia. In order to complete a thorough examination and analysis, including climate change and sago policies from all concerned stakeholders, including the Ministry of Agriculture (MoA), the Ministry of Environment and Forestry (MoEF), the Ministry of National Development Planning (BAPPENAS), the Indonesia Climate Change Trust Fund (ICCTF) and UNDP were evaluated by applying a SWOT analysis framework. The SWOT analysis framework was originally developed for business, marketing and management [26], [27]. It is a strategic planning tool to identify internal factors (strengths and weakness) and external factors (opportunities and threats). These four elements are assessed and investigated to enhance the points of strengths, solve the points of weakness, take profit from opportunities and prepare for the threats [28]. The analysis is then developed based on the facts through a semi-structured interview in each institution to obtain the challenges and strategies that will promote sago for climate change adaptation at a national level. All these interviews were taped separately and the key points recorded in handwritten notes for an accuracy of conversation. In addition, the policy database from FAOLEX and the legal documents from each ministry, including secondary data were reviewed and analyzed to support and cross-validate information collected from interviews and discussions.

\section{Results and discussion}

\subsection{The current status of sago palm at the national level}

Sago palm is a native Indonesian plant covering a total area around 107.906 hectares with a total production of 155.061 tons [29] (Figure 1). The three major areas of sago palm cultivation are Riau, Papua and Sulawesi (Figure 2). However, the national production is only $10 \%$, far below the national sago cultivation potential of 1.128 million hectares [30], [31]. If production was maximized, it could potentially feed approximately 300 million people in the world [32]. While many parts of the world are faced with serious food security challenges, Indonesia has a great potential food supply that can be developed as the basis for food security in a long-term food security [33].

Based on the World Development Indicators database from the World Bank, the Total Gross Domestic Product (GDP) in Indonesia was worth 888.538 billion US dollars in 2014 [34] and sago exports only created 1.96 thousand US dollars in 2013 [29] (Figure 3). From 2011 to 2012, there was a significant reduction of sago exports, dropping to $75.7 \%$. An 
increase of $93.8 \%$ in exports occurred in 2013, but this value was far below other crops such as palm oil ( 17.67 billion US dollars), rubber (6.9o billion US dollars), coffee (1.17 billion US dollars) and cacao (1.51 billion US dollars) [35]. Despite recognition of sago palm as a valuable resource for food and industry since the 1970s, the development remains flat [36]. On the other hand, more than 45 sago-based food products that are found in 21 of 33 provinces in Indonesia [37] have been consumed in their variant forms such as sticky mush, roasted sago, noodles, and snacks. These sago-based food industries have occurred naturally without an integrated comprehensive system. The experiences of local people in consuming sago have proven that sago has a much wider utilization and a great potential to be developed.

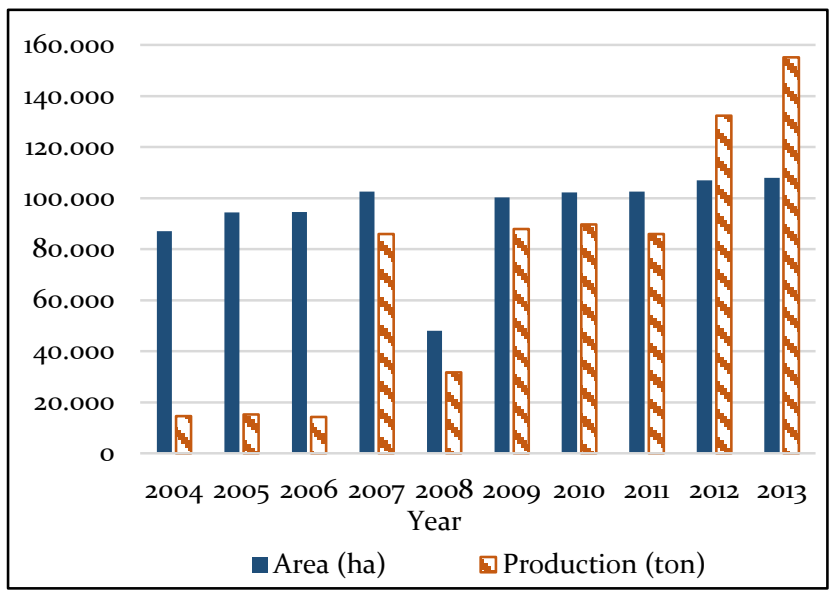

Figure 1 Sago production and area in Indonesia from 2004-2013

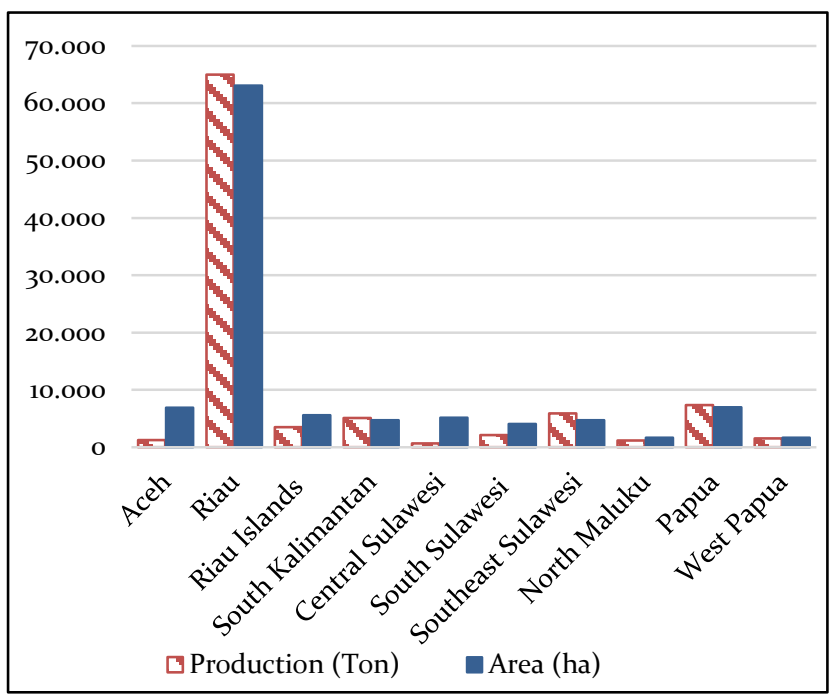

Figure 2 Sago production and area in each province

The sago palm national program is relatively small compared with other annual crops (i.e. palm oil, rubber, and coffee) and also food crops (i.e. rice and corn). From 2012-2014, the sago palm budget was only $0.05 \%$ of the total state budget $(\mathrm{ABPN})$ of the Ministry of Agriculture. The majority of sago palm programs are conducted by the Ministry of Agriculture under the National Food Security Agency and the Directorate of Perennial Crops (Table 1).

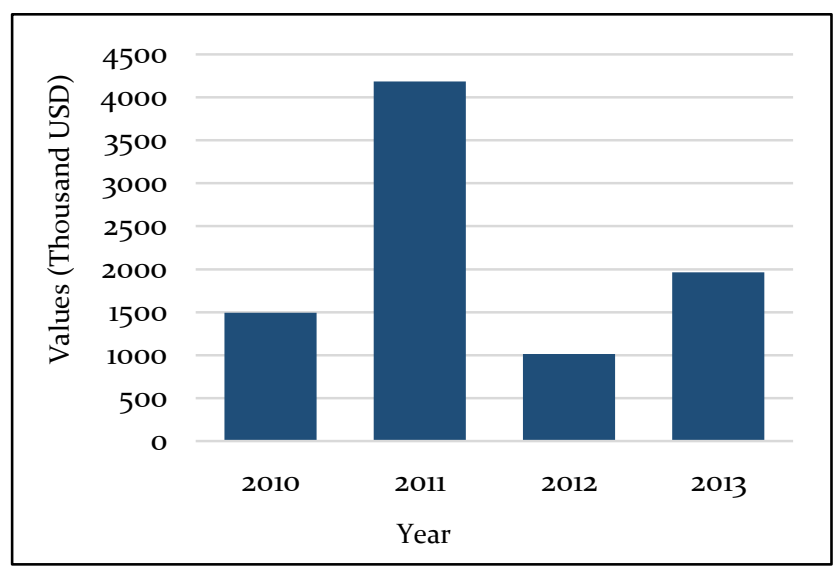

Figure 3 Indonesian sago export between 2010-2013

The National Food Security Agency has been supporting sago palm as a part of a local food diversification program $\left(\mathrm{MP}_{3} \mathrm{~L}\right)$ since 2012 with a total amount of IDR 5.6 billion (420 thousand US dollars) from the APBN budget in nine provinces namely Aceh, Riau, Riau Islands, North Sulawesi, Southeast Sulawesi, South Sulawesi, Maluku and Papua. The program supports sago palm processing training such as refining sago, sago noodles, instant papeda, sago macaroni and analog rice from sago. In addition, the Directorate of Perennial crops has been implementing sago cultivation in Papua and West Papua since 2013 with the total amount of IDR being 31.8 billion (2.38 million US dollars) from the APBN. Their activities included sago palm expansion, sago palm management, sago palm processing and capacity building for farmers and local facilitators. In fact, regardless of numerous advantages, sago is still not treated as a priority crop to develop in supporting economic and food security at the national level.

Table 1 Indonesian sago national programs from 2012-2015

\begin{tabular}{lccccc}
\hline \multicolumn{1}{c}{ Program } & \multicolumn{4}{c}{ Budget (IDR million) } \\
\cline { 2 - 5 } & $\mathbf{2 0 1 2}$ & $\mathbf{2 0 1 3}$ & $\mathbf{2 0 1 4}$ & $\mathbf{2 0 1 5}$ \\
\hline $\begin{array}{l}\text { MP3 (National } \\
\text { security Agency) }\end{array}$ & Food & 1,050 & 350 & - & 4,200 \\
$\begin{array}{l}\text { Sago Development } \\
\text { Program (Directorate } \\
\text { of Perennial crops) }\end{array}$ & - & 16,000 & 8,700 & 7,100 \\
\hline
\end{tabular}

\subsection{Food politic: A shifting of sago social culture}

Sago has been recognized as one of the oldest plants consumed by human beings [38]. It has been used not only for food but also for fertility rituals since ancient times. 
Sago has been identified by the concept of a symbolic connection between the germination of plants and the generation of humans as well as its role in producing life and growth [39]. In Indonesia, the Waropen people of Irian Jaya make sacrifices of sago mush and sago cakes modelled in the shape of a mythical snake, the moon and other figures for 'life crisis' rites for children [40] and in the western area of Jayapura, especially among the Tor river valley people, sago has the highest position in social and religious context [41]. In another area, Ambon, sago is used as a special food for infants in the exclusive ritual as their first food [40] meanwhile in Toraja, South Sulawesi, people prepare small offerings of sago on the path leading to sago washing place to divert evil influences from the work [39], [42]. The people of the Meranti Islands of Riau Province promote sago as a part of their cultural heritage through the 'tual sagu' (sago tree trunks) running contest. The origin of the contest is based on the ancient tradition passed down from their ancestors. The contest has its challengers count the tual sagu before they are transferred into sago processing [43]. These activities underlie the foundation of sago culture at the local area, which has been inherited from people's ancestors, yet, its continuity is still questionable.

Sago also has a very long historical record as a food in Indonesia. It has been consumed as a traditional staple food since ancient times. It was first mentioned in the 13th century by Marco Polo as one of the typical foods in western Sumatera [44] and later it was again described after three centuries along with millet and rice as a common food in Sumatera [45]. Wallace also mentioned that sago was one of small tributes for Sultan of Tidore during the 18th century [46], proved sago was an important commodity in the past. However, nowadays, sago has been replaced with the cultivation of rice and other crops. The shifting of social culture aspects of sago are particularly influenced by political power. This occurs because food is a vehicle for provoking change in policy areas based on political economy and interest groups [47]. The domination of Javanese political power in the Indonesian centralization system emphasized rice policy as part of national food security. Java was well documented as being the primary rice producer; $61.1 \%$ in $1955,57.8 \%$ in 1960 and $55.3 \%$ in 1970 [48]. The government has since developed an agricultural revolution since the 1960 s in order to achieve rice production targets and food-sufficiency by 1984 [49], [50]. Then, in the 1990s, the rice policy was integrated as part of the national transmigration program. In this era, sago gradually acquired a negative image. Due to the national transmigration program, the government provided agricultural land to the people outside Java, however, the lands were not ready to be cultivated so people consumed sago to survive. However, this inadvertently created the impression that sago was a food type of the poor [51]. Furthermore, there was the introduction of a poverty measurement system based on a rice consumption model into the national census, which classified people who consume less than 240 kilograms a year of rice as very poor
[52] which pointed out that eating rice was a status symbol, while sago was associated with poverty. In the 20oos, rice policy continued through the "rice for the poor/RASKIN" policy with subsidies from the government which provided low price for rice in the rural areas [53] and 'paddy pledge program ' in 2015. In addition, the changing social aspects of sago as an edible food source is also related to the behavior and public perception of rice. The rice policies of the past caused a great deal of change in Indonesian food habits. The Food Security Agency pointed out that the pattern of staple food consumption of rice increased from $53.3 \%$ in 1945 to $88.1 \%$ in 1999 and slightly decreased to $78.04 \%$ by 2010 [37]. The high dependency of rice as the main staple food has weakened or even lost the conditions of pluralism in food habits and pluralism in food diversification [54]. In Central Java, for example, the failure of the food diversification program was due to the public's dependence on rice as a cultural barrier [55]. Indeed, we can argue that the lack of support for sago is due to rice biased policy and a lack of appropriate local-based-food policy at the national level.

\subsection{Linking sago with Indonesian policy}

The impacts of climate change manifest in the form of natural hazards, such as extreme weather, floods, and droughts which weaken every country's effort to reduce poverty. Based on research, by 2020, the temperature in Indonesia is estimated to increase by $0.36-0.47^{\circ} \mathrm{C}$ compare to the year 2000 [56]. Furthermore, the rising of SST (Sea surface Temperature) will lead to an increase of extreme weather events. According to research results on Atlantic hurricanes, an increase of SST by $0.52^{\circ} \mathrm{C}$ is correlated with an increase of hurricanes by as much as $40 \%$ [57]. Based on data from the Simple Ocean Data Assimilation/SODA, Indonesia's sea level will rise about $0.8 \mathrm{~mm}$ per year and rainfall has increased to $1.6 \mathrm{~mm}$ per year since 1960 and then $7 \mathrm{~mm}$ per year from 1993 [8] (Figure 4). Indonesia will also experience more intense rainfall, about $2 \%-3 \%$ than the average annual amount in three centuries [4]. According to future projections in 2100, many of the largest cities in Indonesia such as Jakarta, Semarang and Surabaya are expected to suffer from flooding and inundation from sea level rise (Figure 5) and in 2020-2030, extremely high risk of water shortage will occur in several areas such as Java Island, Bali, Sumatera, Nusa Tenggara Barat and South Sulawesi [55] (Figure 6). The distributions of temperature and rainfall during the year are key factors in making decisions regarding what crops to grow, but those will alter due to climate change. It will affect evaporation, precipitation, and water and therefore affect agriculture and food security. Indeed, science is not powerful enough to change natural processes because of climate change, yet it can attempt to mitigate the hazards. Being prepared can only minimize the consequences and impacts of the hazard [58] through climate change adaptation.

According to historical analysis of policy framework adapted from Schmidt [59], the Indonesian government 
already recognized that climate change was a trigger of the food crisis and issued Law 18/2012 and Government Regulation 17/2015 to overcome the situation (Table 2). Therefore, promoting sago palm as a strategy to adapt to climate change appears to be a good option for the purpose of food security, despite there being no specific sago development policy aimed at cultivating and managing it into a main food resource and industry. Sago palm is specifically mentioned only in two regulations; Ministerial Regulation P.19/2009 and Ministerial Regulation 43/2009. The Ministerial Regulation P.19/2009 by Ministry of Forestry on development strategy for national non-timber forest products explained forest utilization is not only oriented with timber as a main product but also that it is exploring non-timber forest products such as rattan, sago, and nipa, meanwhile the Ministerial Regulation 43/2009 by the Ministry of Agriculture mentioned the acceleration of diversification movement based on local resources with support budgeting from APBN to support 36 agricultural commodities including sago. Despite having been created in 2009, there is an indication of low action at the local level in term of planning, implementing, budgeting and evaluating to revive sago palm.

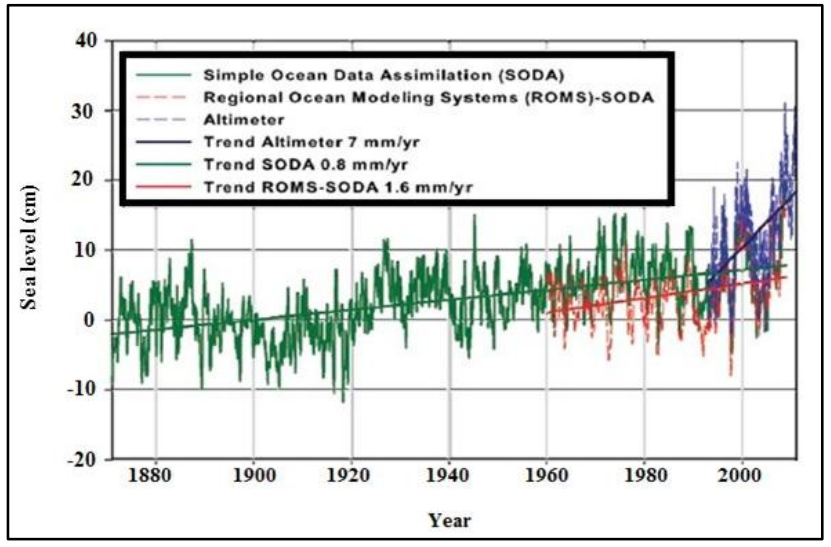

Figure 4 The average of Indonesia`s sea level rise from $1860-2010$

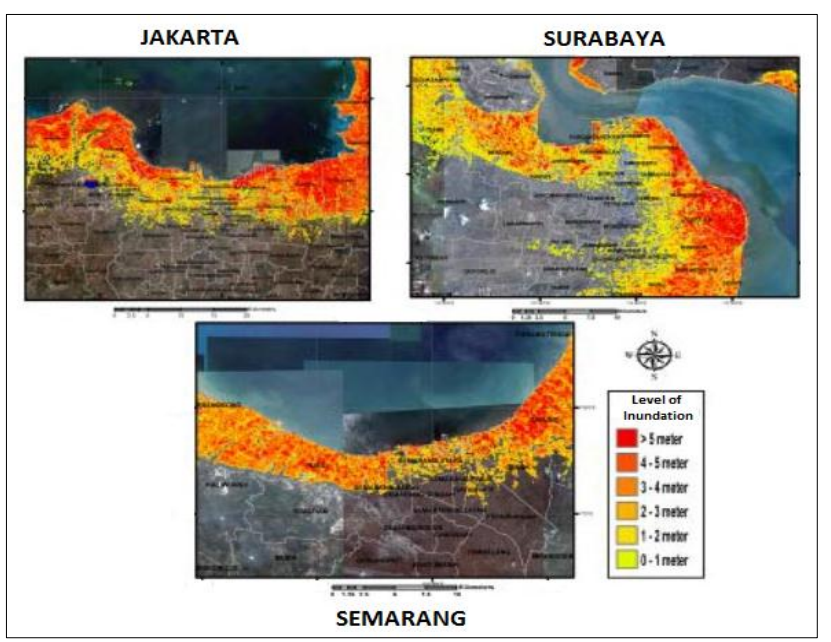

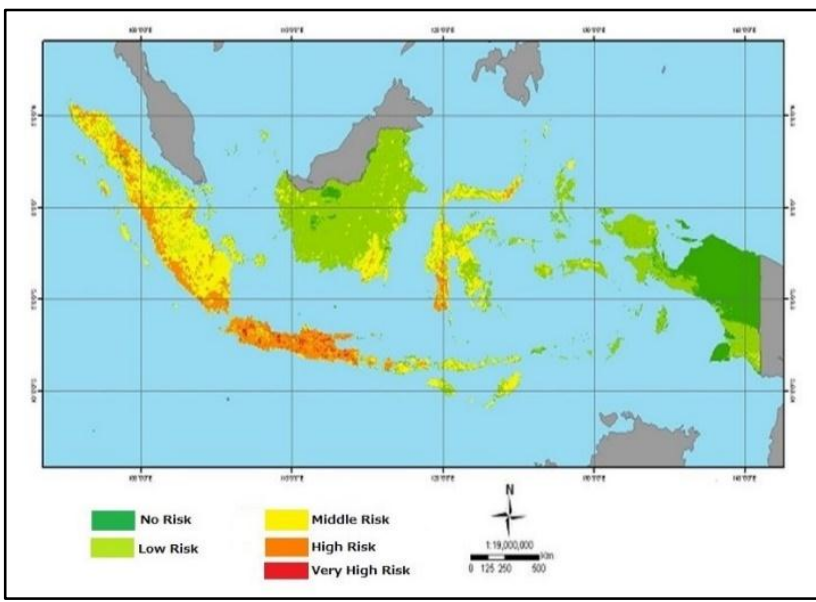

Figure 6 High risk to water shortage in Indonesia for period 2020-2030

In the last two decades, Indonesia has played actively at various national and international negotiations on climate change especially in the policy level but adaptation is still one of the biggest challenges in the level of implementation. The Indonesian RAN-GRK and RAN-API was created in compliance with international commitments acquired under the United Nations Framework Convention on Climate Change (UNFCCC). Particularly, it requires an advanced framework on the instruments which facilitate the national processes of climate change mitigation and adaptation. The overall objectives of those national actions are to reduce the country's vulnerability to climate change including social and economic aspects and to strengthen the strategies and measures for adaptation and mitigation, particularly in the most climate change prone regions. However, the implementation of a national action plan document is still unclear because it is only a framework, there is no solid commitment from all ministries although it has been marked into the Indonesian National Mediumterm Development Plan (RPJMN) of 2015-2019 through Presidential Decree 2/2015.

In 2004, Indonesia published a new policy on decentralization through Law 32/2004. This policy created the legal frame conditions for people's participation in the management of natural resources [6o]. The transfer of responsibility and authority over natural resources from central government to the local level aims to address institutional problems [61]. Therefore, the local government has authority to identify local food potency and strengthen their food security. Nevertheless, climate change is still a new issue so the lack of awareness can be a large negative factor. Without knowledge of the climate change issue, the policy cannot be perfectly implemented at the local level. Minimum interest in local food adaptation approaches (i.e. sago palm), that can create climate-resilient agricultural may contribute to national insecurity. In addition, the difficulty in coordinating institutions and interested stakeholders also pose other challenges in fulfilling an

Figure 5 Future projection of flooding and inundation in 2100 
integrated climate change adaptation towards a sago development program.

Table 2 Commentaries of Indonesian policies related to climate change adaptation and sago palm

\begin{tabular}{llll}
\hline Laws, plans and strategies & Institution & Statement \\
\hline $\begin{array}{l}\text { Law 6/1994: Ratification of } \\
\text { the United Nations }\end{array}$ & $\begin{array}{l}\text { Coordination } \\
\text { by Ministry of } \\
\text { Framework Convention on } \\
\text { Climate Change }\end{array}$ & $\begin{array}{l}\text { Indonesia needs to follow } \\
\text { climate change compliance }\end{array}$ \\
$\begin{array}{l}\text { Law 17/2004: Ratification of } \\
\text { Kyoto Protocol }\end{array}$ & $\begin{array}{l}\text { Coordination } \\
\text { by Ministry of } \\
\text { Environment }\end{array}$ & $\begin{array}{l}\text { Clean } \\
\text { Mechanism to cope with } \\
\text { climate change }\end{array}$ \\
& &
\end{tabular}

Ministerial Regulation P.19/2009: Strategy to develop national non-timber forest products

Presidential Decree 22/2009: Acceleration of food diversification based on local resources

\section{Ministerial Regulation} 43/2009: Acceleration of diversification movement based on local resources

Law 18/2012: Food policy

\section{Ministry} Forestry

of Strategy to explore non-timber forest products such as rattan, sago, and nipa

Coordination The policy recognizes the by Ministry of diversification of local food and Agriculture

Ministry of The government selected 36 Agriculture agricultural commodities with support budget from APBN include sago palm

Ministry of National and local government Agriculture together with community need to foster potential food to cope food crisis because of climate change and disaster

\begin{tabular}{lc} 
National Action for \\
Climate & \multicolumn{1}{c}{ Change } \\
Adaptation & (RAN-API) in \\
2014 &
\end{tabular}

Presidential Decree 2/2015: National Medium-Term Development Plan (RPJMN) 2015-2019 to support climate change adaptation

Government Regulation 17/2015: food security and nutrition

\section{Commentaries}

Lack of policy clarity: In this phase, although Indonesia already ratified the UNFCCC, there is no significant action to support climate change until 2011 through National Action Plan for Reducing Greenhouse Gas Emissions (RAN-GRK)

Lack of policy clarity and difficulty in coordinating institution and interested stakeholders: There is no significant action to support climate change

Lack of policy clarity and lack of reliable political will : There is no significant action related to sago palm as a non-timber forest product

Lack of policy clarity: Despite having been created in 2009, there is no following significant action at the local level in term of planning, implementing, budgeting and evaluating to revive sago as an alternative local food resource

Lack of reliable political will: It is simply assumed that finances will be covered by APBN without further consideration of whether and how this will be connected to local government's budget

Difficulty in coordinating institutions and interested stakeholders and lack of reliable political will: Although the obligation to support food security has been recognized, but in reality, the commitment to use local food resources (i.e. sago palm) as an alternative to adapt to climate change is still minimum

Lack of policy clarity and difficulty in
National

Planning and

Ministry of

Environment and Forestry

Coordinator by Ministry of National Development Planning

Ministry of Commitment from local Agriculture government to provide local food security reserves to reduce food crisis because of climate change and disaster climate change, which focus on economic resilience, living system resilience, ecosystem resilience, specific region resilience (coastal and small island, and urban system) and supporting system resilience

Commitment from national government to support climate change adaptation in 15 pilot provinces coordinating institutions and interested stakeholders: RAN-API is only a framework so there is no solid commitment from all ministries

National action plan docur

Difficulty in coordinating institutions and interested stakeholders

Lack of reliable political will at the local level 


\subsection{SWOT analysis}

Based on the conducted analysis of sago development at the national level, the following matrix (Table 3) summarizes the SWOT analysis in Indonesia. Sago palm historically has comparative advantages over other crops such as palm oil and rubber. As an Indonesian native plant, sago palm has been used as food sources for centuries. In some part of Indonesia, sago food culture is vital for society and passed down from generation to generation. Furthermore, the utilization of sago is not only from its starch, but also from parts such as the stem bark, leaf, and starch waste. The stem bark can be used in construction for making traditional house walls and traditional floors, the leaves can be used for making traditional roofs, and the waste can be used for making animal feed and organic fertilizer. Sago palm is also a source of income and "saving" for farmers because it can be harvested anytime without any significant loss in starch content [62], [63]. The consumption of sago products is also increasing, as an example in South Sulawesi, the popularity of sago food in restaurants has increased with an average of growth of $28.7 \%$ during the last 14 years [64], [50]. Sago has become an important raw material for the food industry and it is predicted that demand for sago in the future will increase.

Despite its strengths there are several weakness and threats have prevented sago palm from reaching its full potential. The growth of sago palm is very slow (8-10 years) longer than other crops so the massive exploitation without rejuvenation/re-planting will lead to loss of resource in the future. In addition, competition among other crops and minimum support from the government become particularly problematic when attempting to promote sago. As an internal factor, traditional farming approaches and a lack of knowledge negatively affect farmers to produce inferior quality starch. Therefore, sago palm management and capacity building are necessary because most of the sago land areas in Indonesia are categorized as sago palm forest which is growing natural without any intensive external technology inputs. Creating a sago industry for export could be an alternative, but it should be noted that international market demand is vulnerable now due to economic crisis.

Table $_{3}$ SWOT analysis

Strengthens
Comparative advantage as a staple food and the production is not
significantly influenced by climate

Support local economies by providing job and income

Existence of sago-based culture in the local area

Favorable weather and land condition for sago production

\section{Opportunities}

Increased sago production and area

Increased health benefits of sago palm among customer

Sago advanced industry development

Market expansion opportunities

\section{Weakness}

Sago palm has long life cycle and takes 8-10 years to harvest longer than other crops

Traditional approach of farming with lack of information to develop best practice and limited capacity to be an estate plantation

Inferior in quality

Lack of support for sago as a crop with minimum financial system and promotion for sago industry

\section{Threats \\ High competition between other crops such as palm oil, cassava, rubber, corn and sweet potato}

International market demand is vulnerable due to economic crisis Lack of recognition in mainstream sago palm into climate change adaptation programs
Based on the SWOT analysis, the government already showed a willingness to support sago especially the Ministry of Agriculture. However, the role of the government is not simply to act as a regulator but also should be actively integrating climate change adaptation frameworks and promoting a sustainable system to develop sago in the future. With its vast and abundant fertile soils, massive local market opportunity and healthy lifestyle, Indonesia can be a major global key producer for sago production and provide future food security for the world. An overlay between land suitability and land use maps of 2000-2004 period revealed there are substantial land areas of about 15.30 million hectares for perennial crops [50] that can be used to increase sago palm cultivation. Maintaining and improving quality and food safety which includes added value to sagobased products are important in order to promote sago palm. Promoting can also be implemented through climate change adaptation programs. The climate change budget allocation in Indonesia for 2010-2014 reached IDR 165.9 trillion (12.47 billion US dollars) with a total of $38.4 \%$ for adaptation climate change activities [65] (Table 4). The financial projection for climate change activities from 20152019 is IDR 680.9 trillion ( 51.2 billion US dollars) covering mitigation IDR 570.8 trillion (42.9 billion US dollars), adaptation activities IDR 109.7 trillion (8.3 billion US dollars) and supporting activities IDR 430.2 billion (32.35 
million US dollars) [66]. This is a great opportunity to develop sago as a strategy to adapt to climate change through sago replanting, diversification of sago products and sago industry based on a small scale.

It is clear that there is a massive opportunity to reorient the national food development into one of sago based food diversification. However, as a developing country, Indonesia also needs to face poverty, food insecurity and climate change. These are major challenges for decision makers, especially at the local level. The poor continue to be significantly constrained when determining their vulnerability to food insecurity. This study discovered that policy at the national level has been implemented and engaged with local governments. The central government authorizes legal instrumentation designed to integrate national policy into local action to strengthening their own adaptation. Yet, the government still needs a strong commitment to revitalizing a food program aligned with a well-defined and developed sago food industry. Changing the dietary behavior and mindset of the people also plays an important role in the reduction of rice dependency. Moreover, as part of a decentralization policy, a number of new food security policies need to be analyzed and mapped including their movements to reflect new developments in the overall food security situation.

To sum up the above challenges, the Indonesian government through the concerned ministries and public institutions should be committed to a national climate change plan which includes clear targets to secure food supply based on local potency. The most important actions could be grouped into main clusters as follows: (a) capacity building and strengthening of public institution in climate change issues, (b) engaging local government and rural communities as a key foundation to conserve sago palm, (c) develop training and awareness programs to preserve and improve the nutritional quality and contribute to the population's food security based on local resources and (c) promoting through incentives and financial resources to support sago development.

\section{Conclusion}

Indonesia is facing major challenges in trying to meet growing population and food demands. Our analysis showed that sago palm has a great potential for development, but it has not yet been chosen as a priority crop. We recognized that the government made several actions that are significantly important when facing the dangers that are triggered by climate change, but there is still a lack of policy or clarity, reliable political will at the local level and difficulty in coordinating institutions and interested stakeholders. The role of the government is not to simply act as a regulator but also to be actively integrated sago palm into a climate change adaptation framework as well as promoting it as a sustainable crop. Furthermore, the government has a significant responsibility in changing the perception of sago by the population of Indonesia and to promote sago cultivation by allocating subsidies and finance institutions to support the sago program of food security as well as ecosystem-based programs. Nevertheless, the introduction and promotion of sago should be performed extensively by using all media networks and campaigns in the mass media, including the preservation of local sago food culture in several areas. In addition, an effective governance is needed to implement policies which promote food availability, household food access and individual food utilization based on local resources.

For climate change policy researchers, our work will allow further studies to compare national and local level policies on food security and potential sago development program details and the discussion of adaptation actions in several other countries. Understanding the role and interplay between them can help bring greater insight and clarity as to why the government chooses to adapt sago as a primary crop or not. In particular, more attention should be given to the potency of local food cultures that survive in Indonesian society so it can advance food security at the local level.

\section{Acknowledgements}

This research is part of a research project sponsored by the Japanese Ministry of Education, Culture, Sports, Science, and Technology (MEXT). We would like to thank the Government of Indonesia for their great assistance.

\section{References}

[1] IPCC. Climate change 2007: The Physical Science Basis, 2007. https://www.ipcc.ch/pdf/assessmentreport/ar4/wg1/ar4_wg1_full_report.pdf. Accessed 21 June 2015.

[2] FAO. Climate change and food security: a framework document. Rome: FAO; 2008.

[3] Leary N, Kulkarni J, Clark S. Assessments of impacts and adaptation to climate change: final report of the AIACC project, 2007.http://start.org/download/publications/AIACCfullreport.p df. Accessed 21 June 2015.

[4] Sari AP, Maulidya M, Butarbutar RN, Sari RE, Rusmantoro W. Executive summary: Indonesia and climate change, working paper on current status and policies, 2007. http://siteresources.worldbank.org/INTINDONESIA/Resources /226271-1170911056314/3428109-

1174614780539/PEACEClimateChange.pdf. Accessed 21 June 2015.

[5] Baumert AK, Herzog T, Pershing J. Navigating the numbers: greenhouse gas data and international policy. United State of America: World Resources Institute; 2005.

[6] Houghton RA. The annual net flux of carbon to the atmosphere from changes in land use 1850 - 1990. Tellus 2003; 5:298-313

[7] Triastuti, U., Tedjakusuma, E., Sriyanti, Girianna, M., Darajati, W., Hernowo, B., Hidayat, Y., Prihartono, B., Simarmata, M., Azdan, M., Armawikarta, A., Hidayat, B., Mintzer, Irving. Indonesia climate change sectoral roadmap ICCSR synthesis report. Jakarta: BAPPENAS; 2009.

[8] Royal Norwegian Embassy. Fact sheet: Norway-Indonesia partnership REDD $\quad+$ 2010. http://www.norway.or.id/PageFiles/404362/FactSheetIndonesia ForestMay252010.pdf. Accessed 21 June 2015.

[9] BAPPENAS. National Action Plan for Climate Change Adaptation (RAN-API). Jakarta: BAPPENAS; 2014. 
[10] Porter JR, Xie L, Challinor AJ, et al. Food security and food production Systems. In: [Field, C.B., V.R. Barros, D.J. Dokken, K.J. Mach, M.D. Mastrandrea, T.E. Bilir, M. Chatterjee, K.L. Ebi, Y.O. Estrada, R.C. Genova, B. Girma, E.S. Kissel, A.N. Levy, S. MacCracken, P.R. Mastrandrea and LLW, ed. Climate Climate change 2014: impacts, adaptations, and vulnerability; part A: global and sectoral aspects. United Kingdom and New York, NY, USA: Cambridge University Press, Cambridge; 2014.

[11] Naylor RL, Vimont BDS, Falcon WP, Burke M. Assessing risks of climate variability and climate change for Indonesian rice agriculture. Proceeding National Academic Science 2007; 114:7752-7757.

[12] Takama T, Setyani P, Aldrian E. Climate change vulnerability to rice paddy production in Bali, Indonesia. In: Handbook of Climate Change Adaptation. Berlin: Springer Berlin Heidelberg; 2014, p. 1-23.

[13] Aldrian E, Takama T, Ulfa AM, Setyani P, Okta R, Mamenun. Vulnerability of paddy and maize to climate variability in Indonesia and vulnerability map of paddy to climate change in bali. http://www.iai.ga.a.u-tokyo.ac.jp/mizo/grene/WS12030305/3-3_EdvinAldrian_120303.pdf. Accessed 22 June 2015.

[14] Ehara H. Sustainable production of sago palm and its utilization for strengthening food security. http://www.fao.org/fileadmin/templates/rap/files/meetings/201 2/120531_iia1.pdf. Accessed 22 June 2015.

[15] Bantacut T. Indonesian staple food adaptations for sustainability in continuously changing climates. J Environ Earth Sci 2014; 4(21):202-216.

[16] Ministry of Health. Directory of food composition. Jakarta: Ministry of Health; 1979.

[17] Alan B. Loreto, Marcelo A. Quevedo, Algerico M. Mariscal, Masanori Okazaki KT. Development of a village-level sago starch grater machine. Philippines: Regional Research and Development Symposium; 2004.

[18] Ehara H, Susanto S, Mizota, S, Hirose T. Sago palm (Metroxylon sagu, Arecaceae) production in the eastern archipelago of Indonesia: Variation in morphological characteristics and pith-dry matter yield. Econ Bot 2000; 54(2):197-206.

[19] Osozawa K. Sago farmers in eastern part of Indonesia. Asano Naonobu Japanese Agric for Relax Regul kashiyo 1998: 257-270.

[20] World Food Programme. Climate change adaptation (CCA): a critical time for action. 2011. https://www.humanitarianresponse.info/system/files/documen ts/files/Final\%2oWFP\%2oDPR\%2oProgramme\%20-

\%20CCA.PDF. Accessed 22 June 2015.

[21] Nishiyama S, Okazaki M, Lina SB, Quevedo MA, Loreto AB. Effect of typhoon on growth of sago palm (Mextroxylon sagu Rottb.) in Pangasugan of Leyte. In: 23rd Annual Meeting of the Society of Sago Palm Studies. Tokyo: The Society of Sago Palm Studies: 2014 .

[22] Flach M. The sago palm: domestication, exploitation and products. Rome: FAO; 1983.

[23] Orwa C, Mutua A, Kindt R, Jamnadass R, Anthony S. Agroforestree database: a tree reference and selection guide. Kenya: World Agroforestry Center; 2009.

[24] Varela RP, Garcia GA, Sarmiento RT, Santillan MM. Lower Agusan river basin towards increasing the community's adaptive capacity to climate change for DRR. Philippines; 2014.

[25] Chan S. Sago sack of gold. Malaysian Business. February 16, 1997.

[26] Terrados, J, Almonacid, G, Hontoria L. Regional energy planning through SWOT analysis and strategic planning tools: impact on renewables development. Renew Sustain Energy 2007; 11(6):1275-1287.

[27] Chen WM, Kim H, Yamaguchi H. Renewable energy in eastern Asia: Renewable energy policy review and comparative SWOT analysis for promoting renewable energy in Japan, South Korea, and Taiwan. Energy Policy 2014; 74:319-329.

[28]Jaber JO, Elkarmi F, Alasis E, Kostas A. Employment of renewable energy in Jordan: current status, SWOT and problem analysis. Renew Sustain Energy 2015; 49:490-499.

[29] Directorate of Perennial Crops. Tree Crop Estate Statistic of Indonesia 2013-2015. Jakarta: Ministry of Agriculture; 2015.

[30] Pietries D. The Study about sago forest in Maluku. Bogor: Bogor Agriculture Institute; 1996.

[31] Rindengan B, Karaouw S. Potential of sago for plastic raw material and food security. Manado: Research Center for Coconut and Palm; 2003.

[32] Agency for Assessment and Application of Technology. Opportunities and challenges of sago starch as a food resource. In: Sago Business Meeting. Jakarta: BPPT; 2015.

[33] Flach M. The sago palm and its yield potential. TANKOOLIN, M. A. ed. Malaysia: The 1st international sago symposium 1976, 1977, p. 157-177.

[34] World Bank. The Gross Domestic Product of Indonesia. 2015. http://data.worldbank.org/country/indonesia. Accessed 28 June 2015.

[35] Ministry of Agriculture. The statistic of agricultural commodities export-import: 2001-2013. Jakarta: Minsitry of Agriculture; 2014.

[36] Regional Research and Development Agency. Sago commodity development as an alternative food in South Sulawesi. South Sulawesi: BALITBANGDA; 2008.

[37] Food Security Agency. Roadmap of Food Diversification 20112015. Jakarta: Ministry of Agriculture; 2012.

[38]Avé J. Sago in insular South-East Asia: Historical aspects and contemporary use. Malaysia: The first International Sago Symposium 1976, 1977: p. 21-30.

[39] Ruddle K, Johnson D, Townsend PK, Ress JD. Sago in myth and ritual. In: Palm sago: a tropical starch from marginal lands. Canberra and Honolulu: Australian National University Press and East-West Center; 1978, p. 70-94.

[40]Held GJ. The Papuas of Waropen. Netherland: The Hague: Martinus Nijhoff; 1957. P. 143-176.

[41] Oosterwal G. People of the Tor. Assen: Royal Van Gorcum; 1961. p. 57.

[42] Adriani N, Kruyt AC. De Bare'e Sprekende Toradjas van MiddenCelebes. (Translation by J. K. Moulton, ed.). Amsterdam: Human Relations Area Files; 1951.

[43] Nur, Sabara. Tual sago running contest is only in Meranti. 2015. http://riaugreen.com/view/Meranti/9225/Lomba-Lari-di-AtasTual-Sagu--Hanya-Ada-di-Meranti. Accessed 24 November 2015.

[44]Polo M. The travels of Marco Polo. Komroff, ed. New York: Liveright Publishing Corp; 1930.

[45] Ruddle K, Johnson D, Townsend PK, Ress JD. Sago as subsistence, complementary, and emergency food. In: Palm Sago: A Tropical Starch from Marginal Lands. Canberra and Honolulu: Australian National University Press and East-West Center; 1978, p. 42-69.

[46] Wallace AR. The Malay archipelago. 1869. https://ebooks.adelaide.edu.au/w/wallace/alfred_russel/malay/ chapter36.html. Accessed 7 June 2016. 
[47] Reynolds CJ. Tipping the scales: A new understanding of food's power in the political sphere. Int J Interdiscip Soc Sci 2010; 7(5):295-304.

[48]Afiff S, Timmer P. Rice policy in Indonesia. Philippines: International Rice Research Institute; 1971.

[49]FAO. Indonesia and FAO achievements and success stories. Italy: FAO; 2011.

[50] Mulyani A, Las I. Land resources potential and optimization of bioenergy producing commodities development in Indonesia. Research Dev Agric 2008; 27(1):31-41.

[51] Metaragakusuma AP. Sago development in South Sulawesi: its current situation, new movement and the succession of the sago culture by small scale farmers (Unpublished master thesis). Japan: Ehime University; 2014.

[52] Sajogyo. Poverty lines and minimum food needs. Yogyakarta: Aditya Media; 1996.

[53] Girsang W. Socio-economic factors that have influenced the decline of sago consumption in small islands: a case in Rural Maluku, Indonesia. South Pacific Study 2014; 34(2):99-116.

[54] Budiarto T. An introduction to you on food diversification. 2013. http://www.kompasiana.com/paansiih/sebuah-pengantaruntuk-anda-tentang-diversifikasipangan_552ac8b56ea834a958552d2a. Accessed 25 November 2015.

[55] Widyanti A, Sunaryo I, Kumalasari A. Reducing the dependency on rice as staple food in Indonesia- a behavior intervention approach. J ISSAAS 2014; 20(1):93-103.

[56] Ministry of Environment. Indonesia: The second national communication under the United Nations Framework Convention on Climate Change. Jakarta: Minsitry of Environment; 2010.

[57] Saunders MA, Lea A. Large contribution of sea surface warming to recent increase in Atlantic hurricane activity. Nature 2008; 45:557.

[58] Aggarwal, PK, Joshi PK, Ingram JS, Gupta R. Adapting food systems of the Indo-Gangetic plains to global environmental change: key information needs to improve policy formulation. Env Sci Policy 2004; 7:487-498.

[59] Schmidt L, Prista P, Saraiva T, O’Riordan T, Gomes C. Adapting governance for coastal change in Portugal. Land use policy. 2013; 31:314-325.

[6o]McCarthy J. The changing regime: forest property and reformation in Indonesia. Dev Change 2000; 31:91-129.

[61] Wibowo D, Byron NR. Deforestation mechanism: a survey. Int J Soc Econ 1999; 26:455-474.

[62] Ishizaki A. Sago, an attractive renewable resource which saves human's crisis of environment and energy. Malaysia: ASEAN Sago Symposium; 2009.

[63] Tek-Ann C, Isa AH, Mohayidin MG. An economic study of the sago industry in Malaysia. 1997. http://spiru.cgahr.ksu.edu/proj/iwcspp/pdf2/7/1720.pdf. Accessed 20 November 2015.

[64]Genda N. The utilization and future possibility of sago palm in Indonesia (Unpublished master thesis). Japan: Ehime University; 2014.

[65] ICCTF. ICCTF Business Plan 2014-2020. Jakarta: Ministry of National Planning (BAPPENAS); 2014.

[66]BAPPENAS. Priority Activity for RPJMN 2015-2019. Jakarta: BAPPENAS; 2015. 